\title{
An assessment of microclimatic conditions inside vegetated and non-vegetated small-scale open spaces in the Athens urban environment
}

\author{
Melas E.*, Thoma E. and Tsiros I. \\ Agricultural University of Athens, Laboratory of General and Agricultural Meteorology, lera Odos 75, 11855, Athens, Greece \\ Received: 08/08/2021, Accepted: 21/10/2021, Available online: 26/10/2021 \\ *to whom all correspondence should be addressed: e-mail: emm.melas@gmail.com \\ https://doi.org/10.30955/gnj.003903
}

\section{Graphical abstract}

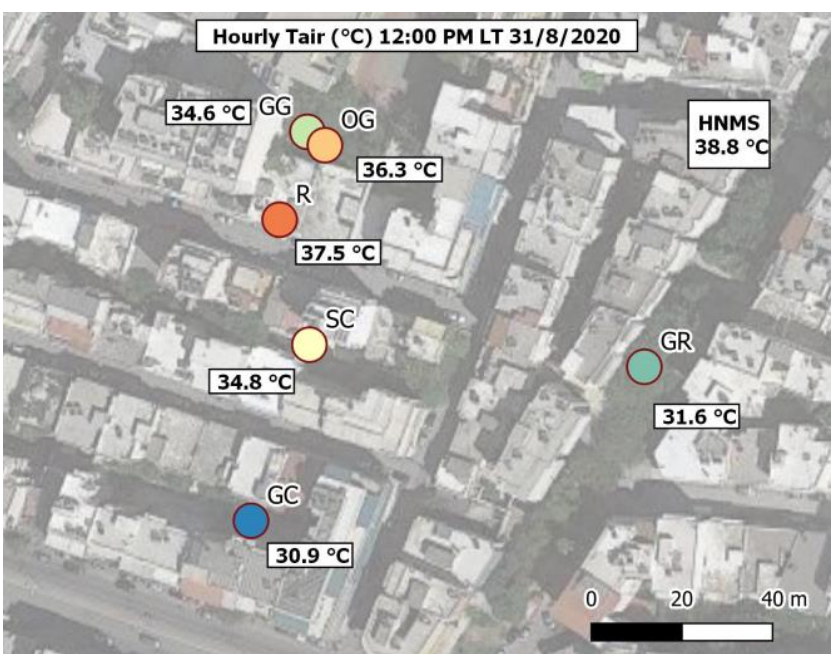

\section{Abstract}

This study is aimed at quantifying the contribution of small urban green spaces to mitigate adverse bioclimatic conditions within the urban environment of Athens during summer and investigate their thermal profile during a warm, a cold and a transitional period. Six green and nongreen sites inside a typical urban cluster in the city of Athens were selected and monitored. Descriptive statistics data were calculated and evaluated for air temperature values and air temperature differences measured at a reference site. Statistical analysis was carried out in order to examine potential statistically significant differences. Results showed that vegetated sites showed a stronger cool island pattern compared to non-vegetated open spaces during the warm period whereas the effect is minimized during the cold period. During the transitional period vegetated and nonvegetated shaded locations was found to present similar heat island pattern.

Keywords: Urban climate, Urban Heat Island, Cool Island, small green spaces, courtyards, mediterranean.

\section{Introduction}

Large urban green spaces have been examined extensively for their qualities and cooling effect (Bowler et al., 2010). In the city of Athens, large urban green spaces (i.e. parks) have been found to play a critical role in the pattern of the Urban Heat Island (UHI) phenomenon but their cooling effect holds only for a few meters off their perimeter due to anthropogenic heat and vegetation absence (Zoulia et al., 2009). The UHI in the city of Athens is particularly intense with the difference in average air temperature between urban and suburban locations reaching $4.5 \mathrm{~K}$ (Giannopoulou et al., 2011; Livada et al., 2002). The thermal behavior of urban small spaces (green or nongreen) whose existence may not be the result of intentional design has not been investigated in terms of microclimate and also in relation with their potential contribution to heat island mitigation. One of the first quantitative studies in Greece examining these spaces showed that under strong heat wave conditions, air temperature values in small, vegetated areas appear to be lower by $7 \mathrm{~K}$ compared to the surrounding area (Tsiros \& Hoffman, 2014). Also, densely vegetated courtyards may be used as passive cooling tools for buildings, contributing to the reduction of energy consumption during the summer months (Tsiros, 2010). The present study is aimed at quantifying the contribution of small urban green spaces to mitigate adverse bioclimatic conditions within the urban environment of Athens during summer and also investigates their thermal profile during a warm, a cold and a transitional period.

\section{Sites and data}

Measurement sites were selected in a typical neighborhood of Athens, Patisia, including three courtyards located in the interior of urban blocks, one roof level open to the sky, and one pedestrian road all located within a $65 \mathrm{~m}$ radius. In the first courtyard two monitoring sites were selected, one in the center of a rear-wooded garden characterized by sunlit conditions (Open Garden) and one in the same garden but under tree canopy (Green Garden). The second courtyard is a typical 
non-vegetated small backyard (Shaded Courtyard) shaded mainly from the surrounding walls and the third courtyard is a backyard shaded from dense tree canopies along with surrounding walls (Green Courtyard). Such backyards are mainly the result of regulations due to high building density construction in the 1950-1970 period in Athens (Tsianaka, 2006). The roof level location (Roof) is on the top of the two-story building next to the first courtyard and the pedestrian road has very dense vegetation with tall trees in the center of it. All the locations except for the Roof, are shaded by adjacent buildings. The buildings have aproximately the same height $(\approx 17 \mathrm{~m})$ in the same N-NE orientation. Elefsina station (Hellenic National Meteorological Service - HNMS), located approximately $16.3 \mathrm{~km}$ from the urban cluster, was chosen as a reference site. Small air temperature (and air humidity) loggers (six Onset Hobo MX2302A) were installed in all six locations for simultaneous measurements of air temperature (Tair, ${ }^{\circ} \mathrm{C}$ ). All instruments were fixed inside white aluminum louvered solar radiation shields, placed in approximate 1,7 $\mathrm{m}$ of the ground and programmed in fifteen-minute interval logging. Measurements were conducted in a three-month period, August, October and December of 2020.

\section{Methodology - statistical analysis}

Air temperature data recorded in-site were averaged in one-hour timesteps and hourly minimum and maximum values were also calculated. Data obtained from the HNMS Station where downscaled from three-hour values to one-hour values using linear interpolation. For each location (six in urban cluster and one in reference site) the same number $(n=733)$ of hourly Tair measurements was obtained and thus six $\Delta$ Tair sets (each urban positions' Tair minus reference site's Tair) of the same number were calculated. $\Delta$ Tair negative values indicate cooling patterns (cool island effect) and positive values indicate warming patterns (heat island effect). Descriptive statistics data were calculated and evaluated for air temperature values and air temperature differences, measured at the reference site. Tair data showed a non-normal distribution and thus Spearman correlation coefficients $\left(r_{s}\right)$ were used to examine the association between them. Kruskal-Wallis $\mathrm{H}$ test was used to identify the potential statistically significant differences between the position profiles in Tair and $\Delta T$ Tair. Distributions of Tair and $\Delta T$ Tair values were similar for all groups, as assessed by visual inspection of a boxplot. Pairwise comparisons were performed using Dunn's procedure with a Bonferroni correction for multiple comparisons. In results adjusted $p$-values are presented.

\section{Results}

\subsection{Warm period}

Maximum hourly Tair $\left(38.8^{\circ} \mathrm{C}\right)$ for warm period (August) in HNMS was recorded in 31/8/2020, 12:00 pm LT. Tair recorded at the same time in the other locations was $34.8^{\circ} \mathrm{C}$ for Shaded Courtyard, $37.5^{\circ} \mathrm{C}$ for Roof, $36.3^{\circ} \mathrm{C}$ for Open Garden, $34.6^{\circ} \mathrm{C}$ for Green Garden, $31.6^{\circ} \mathrm{C}$ for Green Road and $30.9^{\circ} \mathrm{C}$ for Green Courtyard. Among the three vegetated locations the lowest mean Tair were recorded in the Green Courtyard $\left(28.1^{\circ} \mathrm{C}\right.$ ) (Table 1a) and Green Garden and Green Road showed similar values $\left(28.8^{\circ} \mathrm{C}\right.$ and $28.4^{\circ} \mathrm{C}$ respectively). The highest mean daily range of Tair was found at the Roof $(10.7 \mathrm{~K})$ and the lowest in the Green Courtyard (5.9 K). Hourly average air temperature differences (Figure 1) show strong cool island patterns in the morning until noon with peak hour approximately 9:00 and an extended peak period of eleven hours (05:0015:00) for the Green Courtyard. Heat island values in Green Courtyard and Green Road peak around midnight, for Open Garden around 15:00 and for the rest of the sites around 18:00 - 19:00. A strong positive correlation was found between all Tair profiles of the urban cluster $\left(p<0.001,0.87 \leq r_{s} \leq 0.99\right)$ and a weaker between HNMS Station profile and the cluster's profiles ( $p<0.001,0.42 \leq r_{s}$ $\leq 0.65$ ), with strongest the one between Shaded Courtyard and Green Garden ( $\left.r_{s}=0.99\right)$ and the one between Open Garden and Green Garden ( $r_{s}=0.99$ also). The weakest correlation was the one between Green Courtyard and HNMS Station ( $\left.p<0.001, r_{s}=0.42\right)$. Roof showed statistically significant differences with Green Garden, Green Road, Green Courtyard and Open Garden ( $p<0.001$ in all cases). Shaded Courtyard showed statistically significant differences with Green Road and Green Courtyard $(p<0.001$ both), with Open Garden $(p=0.001)$ and a marginal difference with Green Garden $(p=0.049)$. Finally, Green Garden showed statistically significant differences with Green Courtyard $(p=0.013)$. Relative humidity values were found to be similar across all locations (mean values from $41 \%$ to $46 \%$, minimum from $17 \%$ to $22 \%$ and maximum from $90 \%$ to $96 \%$.

\subsection{Transitional period}

During the transitional period (October) among the three vegetated locations the lowest mean Tair was recorded in the Green Courtyard $\left(20.4^{\circ} \mathrm{C}\right.$ ) (Table 1b). At the Green Garden and the Green Road the lowest mean Tair was $21.2{ }^{\circ} \mathrm{C}$ presenting almost the same mean value with Shaded Courtyard $\left(21.1^{\circ} \mathrm{C}\right)$. The highest mean daily range of Tair was found in the Roof (9.5 K) and the lowest in Green Courtyard $(4 \mathrm{~K})$. Hourly average air temperature differences (Figure 1) show strong cool island patterns in the morning until noon (except for Roof) with peak hour approximately 9:00 and an extended peak period of ten hours (06:00-16:00) for Green Courtyard. Heat island values in Green Courtyard peak at 00:00 and in Green Road peak around 22:00. For the rest of locations heat island peaks around 18:00. A strong positive correlation was found between all Tair profiles of the urban cluster $\left(p<0.001,0.79 \leq r_{s} \leq 1\right)$ and a weaker between HNMS Station profile and the cluster's profiles ( $\left.p<0.001,0.57 \leq r_{s} \leq 0.78\right)$, with strongest the one between Open Garden and Green Garden $\left(r_{s}=1\right)$. The weakest correlation was the one between Green Courtyard and HNMS Station ( $p<0.001$, $\left.r_{s}=0.57\right)$. Between all Tair profiles Roof shows statistically significant differences with all other locations $(p<0.001$ in all cases except with Green Road, $p=0.002$ ). Open Garden's profile is significantly different with Green Road $(p=0.001)$, Green Garden $(p=0.007)$ and Shaded Courtyard 
( $p=0.017$ ) while Green Courtyard differs significantly from Green Road, Green Garden and Shaded Courtyard $(p<0.001$ in all cases). Relative humidity values were found to be similar across all locations (mean values from $60 \%$ to $66 \%$, minimum from $25 \%$ to $31 \%$ and maximum from $92 \%$ to $95 \%$.

Table 1. Air temperature $\left(T_{\text {air }}\right)$ and Air temperature differences $\left(\Delta T_{\text {air }}\right)$ between examined locations and the reference site in examined locations during warm (a) transitional (b) and cold (c) period

\begin{tabular}{|c|c|c|c|c|c|c|c|}
\hline & Mean & SD & Min (Abs) & Max (Abs) & Min (DM) & Max (DM) & Range (DM) \\
\hline \multicolumn{8}{|l|}{ (a) } \\
\hline$T_{\text {air }}\left({ }^{\circ} \mathrm{C}\right)$ Green Garden & 28.8 & 3.4 & 19.8 & 39.2 & 24.9 & 33.8 & 8.9 \\
\hline$T_{\text {air }}\left({ }^{\circ} \mathrm{C}\right)$ Green Courtyard & 28.1 & 2.5 & 20.5 & 34.9 & 25.4 & 31.3 & 5.9 \\
\hline$T_{\text {air }}\left({ }^{\circ} \mathrm{C}\right)$ Green Road & 28.4 & 2.7 & 21.2 & 36.1 & 25.3 & 32.2 & 6.8 \\
\hline$T_{\text {air }}\left({ }^{\circ} \mathrm{C}\right)$ Roof & 30.0 & 4.2 & 21.3 & 39.9 & 25.0 & 35.8 & 10.7 \\
\hline$T_{\text {air }}\left({ }^{\circ} \mathrm{C}\right)$ Shaded Courtyard & 29.4 & 3.3 & 20.3 & 39.1 & 25.7 & 34.3 & 8.6 \\
\hline$T_{\text {air }}\left({ }^{\circ} \mathrm{C}\right)$ Open Garden & 28.7 & 3.9 & 19.5 & 39.8 & 24.4 & 35.1 & 10.6 \\
\hline HNMS & 28.6 & 3.8 & 18.0 & 38.0 & 18.0 & 38.8 & 20.8 \\
\hline$\Delta T_{\text {air }}\left({ }^{\circ} \mathrm{C}\right) \mathrm{GG}-\mathrm{E}$ & 0.2 & 3.3 & & & -6.0 & 4.2 & 10.3 \\
\hline$\Delta T_{\text {air }}\left({ }^{\circ} \mathrm{C}\right) \mathrm{GC}-\mathrm{E}$ & -0.5 & 3.4 & & & -6.2 & 3.8 & 10.0 \\
\hline$\Delta T_{\text {air }}\left({ }^{\circ} \mathrm{C}\right) \mathrm{GR}-\mathrm{E}$ & -0.2 & 3.4 & & & -6.2 & 3.9 & 10.1 \\
\hline$\Delta T_{\text {air }}\left({ }^{\circ} \mathrm{C}\right) \mathrm{R}-\mathrm{E}$ & 1.4 & 3.2 & & & -5.0 & 6.1 & 11.2 \\
\hline$\Delta T_{\text {air }}\left({ }^{\circ} \mathrm{C}\right) \mathrm{SC}-\mathrm{E}$ & 0.7 & 3.1 & & & -5.4 & 4.5 & 9.9 \\
\hline$\Delta T_{\text {air }}\left({ }^{\circ} \mathrm{C}\right)$ OG-E & 0.1 & 3.7 & & & -6.3 & 4.2 & 10.5 \\
\hline \multicolumn{8}{|l|}{ (b) } \\
\hline$T_{\text {air }}\left({ }^{\circ} \mathrm{C}\right)$ Green Garden & 21.2 & 3.4 & 14.9 & 30.9 & 18.4 & 22.5 & 4.0 \\
\hline$T_{\text {air }}\left({ }^{\circ} \mathrm{C}\right)$ Green Courtyard & 20.4 & 2.5 & 15.2 & 26.4 & 25.4 & 31.3 & 5.9 \\
\hline$T_{\text {air }}\left({ }^{\circ} \mathrm{C}\right)$ Green Road & 21.2 & 3.0 & 15.3 & 29.5 & 18.6 & 24.4 & 5.9 \\
\hline$T_{\text {air }}\left({ }^{\circ} \mathrm{C}\right)$ Roof & 21.8 & 4.0 & 14.4 & 34.3 & 17.8 & 27.3 & 9.5 \\
\hline$T_{\text {air }}\left({ }^{\circ} \mathrm{C}\right)$ Shaded Courtyard & 21.1 & 3.0 & 15.3 & 29.7 & 18.5 & 24.1 & 5.6 \\
\hline$T_{\text {air }}\left({ }^{\circ} \mathrm{C}\right)$ Open Garden & 20.7 & 3.3 & 14.5 & 29.9 & 17.5 & 24.6 & 7.0 \\
\hline HNMS & 20.9 & 3.6 & 13.2 & 32.0 & 13.2 & 32.0 & 18.8 \\
\hline$\Delta T_{\text {air }}\left({ }^{\circ} \mathrm{C}\right) \mathrm{GG}-\mathrm{E}$ & 0.3 & 2.7 & & & -5.2 & 3.3 & 8.5 \\
\hline$\Delta T_{\text {air }}\left({ }^{\circ} \mathrm{C}\right) \mathrm{GC}-\mathrm{E}$ & -0.5 & 3.0 & & & -5.3 & 3.3 & 8.6 \\
\hline$\Delta T_{\text {air }}\left({ }^{\circ} \mathrm{C}\right) \mathrm{GR}-\mathrm{E}$ & -0.3 & 2.8 & & & -4.9 & 3.6 & 8.5 \\
\hline$\Delta T_{\text {air }}\left({ }^{\circ} \mathrm{C}\right) \mathrm{R}-\mathrm{E}$ & 0.9 & 2.5 & & & -4.8 & 3.9 & 8.7 \\
\hline$\Delta T_{\text {air }}\left({ }^{\circ} \mathrm{C}\right) \mathrm{SC}-\mathrm{E}$ & 0.2 & 2.9 & & & -4.9 & 3.5 & 8.5 \\
\hline$\Delta T_{\text {air }}\left({ }^{\circ} \mathrm{C}\right) \mathrm{OG}-\mathrm{E}$ & 0.2 & 2.7 & & & -5.5 & 2.8 & 8.3 \\
\hline \multicolumn{8}{|l|}{ (c) } \\
\hline$T_{\text {air }}\left({ }^{\circ} \mathrm{C}\right)$ Green Garden & 13.7 & 2.1 & 8.7 & 19.1 & 11.5 & 16.2 & 4.8 \\
\hline$T_{\text {air }}\left({ }^{\circ} \mathrm{C}\right)$ Green Courtyard & 13.4 & 1.6 & 9.2 & 17.6 & 11.8 & 15.1 & 3.3 \\
\hline$T_{\text {air }}\left({ }^{\circ} \mathrm{C}\right)$ Green Road & 14.0 & 2.0 & 9.6 & 19.0 & 12.1 & 16.4 & 4.4 \\
\hline$T_{\text {air }}\left({ }^{\circ} \mathrm{C}\right)$ Roof & 14.1 & 2.6 & 8.5 & 22.2 & 11.5 & 18.3 & 6.8 \\
\hline$T_{\text {air }}\left({ }^{\circ} \mathrm{C}\right)$ Shaded Courtyard & 13.7 & 1.9 & 9.4 & 18.3 & 11.9 & 15.9 & 4.0 \\
\hline$T_{\text {air }}\left({ }^{\circ} \mathrm{C}\right)$ Open Garden & 13.4 & 2.2 & 8.5 & 18.9 & 11.1 & 16.1 & 5.0 \\
\hline HNMS & 13.0 & 2.6 & 7.0 & 19.8 & 7.0 & 19.8 & 12.8 \\
\hline$\Delta T_{\text {air }}\left({ }^{\circ} \mathrm{C}\right) \mathrm{GG}-\mathrm{E}$ & 0.6 & 1.9 & & & -3.2 & 3.0 & 6.2 \\
\hline$\Delta T_{\text {air }}\left({ }^{\circ} \mathrm{C}\right) \mathrm{GC}-\mathrm{E}$ & 0.3 & 2.2 & & & -3.2 & 3.0 & 6.3 \\
\hline$\Delta T_{\text {air }}\left({ }^{\circ} \mathrm{C}\right) \mathrm{GR}-\mathrm{E}$ & 0.9 & 2.1 & & & -2.8 & 3.4 & 6.2 \\
\hline$\Delta T_{\text {air }}\left({ }^{\circ} \mathrm{C}\right) \mathrm{R}-\mathrm{E}$ & 1.0 & 1.9 & & & -2.9 & 3.5 & 6.4 \\
\hline$\Delta T_{\text {air }}\left({ }^{\circ} \mathrm{C}\right)$ SC-E & 0.7 & 2.0 & & & -3.0 & 3.3 & 6.3 \\
\hline$\Delta T_{\text {air }}\left({ }^{\circ} \mathrm{C}\right)$ OG-E & 0.4 & 1.9 & & & -3.4 & 2.7 & 6.1 \\
\hline
\end{tabular}

Abbreviations: SD, Standard Deviation; Abs, Absolute; DM, Daily Mean

\subsection{Cold period}

During cold period (December) among the three vegetated locations the lowest mean $T_{\text {air }}$ value were recorded in the Green Courtyard $\left(13.4{ }^{\circ} \mathrm{C}\right.$ ) (Table 1c) while the Green Garden and the Green Road showed similar values $\left(13.7{ }^{\circ} \mathrm{C}\right.$ and $14.0{ }^{\circ} \mathrm{C}$, respectively). The highest mean daily range of $T_{\text {air }}$ was found at the Roof $(6.8 \mathrm{~K})$ and the lowest in the Green Courtyard (3.3 K). Hourly average air temperature differences (Figure 1 ) show strong cool island patterns in the morning (8:00-10:00) and an extended period of six hours (08:00-15:00) for the Green Courtyard. Heat island values peak around 21:00 in all the examined locations whereas in the case of the Green Courtyard a strong peak period is observed from 21:00 till 06:00. A strong positive correlation was found between all $T_{\text {air }}$ profiles of the urban cluster $\left(p<0.001,0.9 \leq r_{s} \leq 0.99\right)$ and a weaker between HNMS Station profile and the cluster's profiles $\left(p<0.001,0.59 \leq r_{s} \leq 0.7\right)$, with strongest the one between Shaded Courtyard and Green Road $\left(r_{s}=0.99\right)$ and 
the one between Open Garden and Green Garden ( $r_{s}=0.99$ also). The weakest correlation was the one between Green Courtyard and HNMS Station ( $\left.p<0.001, r_{s}=0.59\right)$. Between all $T_{\text {air }}$ profiles Roof shows statistically significant differences with Green Garden ( $p=0.001)$, Open Garden $(p<0.001)$, Green Courtyard $(p<0.001)$ and Shaded Courtyard ( $p=0.003)$. Green Road's profile is significantly different with Open Garden $(p<0.001)$ and Green Courtyard $(p<0.001)$. Relative humidity values were found to be similar across all locations (mean values from $75 \%$ to $79 \%$, minimum from $42 \%$ to $55 \%$ and maximum from $94 \%$ to $97 \%$.

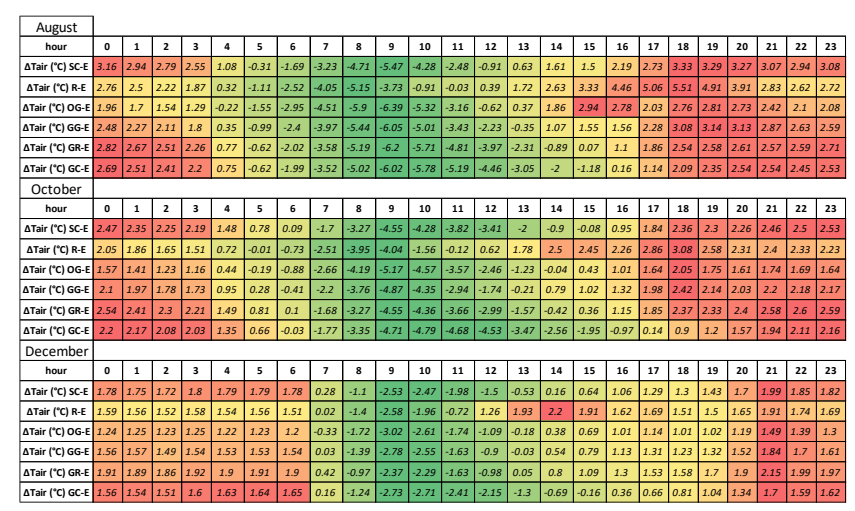

Figure 1. Hourly average air temperature differences ( $\left.\Delta T_{\text {air }}\right)$ during all periods. Negative values (green cells) indicate cool island effect and positive values (yellow, orange and red cells), heat island effect. Values are color-scaled independently for every measuring position. Abbreviations: R-E, Roof - HNMS Station; OG-E, Open Garden - HNMS Station; GG-E, Green Garden - HNMS Station; GC-E, Green Courtyard - HNMS Station; GR-E, Green Road - HNMS Station; SC-E, Shaded Courtyard HNMS Station.

\section{Concluding remarks}

This study analyzed data from in-situ measurements concerning air temperature patterns in typical small urban open spaces (vegetated and non-vegetated) for three months during the year of 2020 in the city of Athens. Vegetated sites showed a stronger cool island pattern compared to non-vegetated open spaces during the warm period whereas the effect is minimized during the cold period. Humidity appears to affect the locations in an almost identical way, considering the proximity of the sites. During the transitional period vegetated and nonvegetated shaded locations show similar heat island patterns. Moving from warm to cold period there is approximately a $2 \mathrm{~K}$ decrease in mean daily $\Delta T_{\text {air }}$ for all locations, in every period. Cool island patterns during summer daytime (5.4-6.3 K) found to be in agreement with similar research in the area (Tsiros \& Hoffman, 2014) and comparable with those produced from very small parks (Wong et al., 2021). Limitations of the study should also be mentioned. First, difficulties in location selection and monitoring were faced mainly due to the fact that all locations were inside private properties. All locations were chosen according to their design and the relative ease of access they offer. Green urban spaces appear as cooler locations inside the urban cluster during the warm period. Further research, however, should be conducted in the form of bioclimatological modeling of the whole cluster to quantitatively evaluate parameters such as the shade effect from the surrounding buildings and also the combined effect of all small green spaces as a network and its effect on the microclimate conditions at a neighborhood scale.

\section{Acknowledgments}

This Research Project is co-financed by Greece and the European Union (European Social Fund) through the Operational Program "Human Resources Development, Education and Lifelong Learning 2014-2020» and the Program encoded EDBM103, titled "Support for researchers with an emphasis on young researchers-cycle B' ", in the context of the project "Contribution of small green spaces to the adaptation of cities to climate change in the Mediterranean Basin" (MIS 5048918). The authors would like to thank Mrs Asi Trianti, Ms Pinelopi Papapanou, Ms Nota Koromila and Mr Georgios Kolias for their help with the appropriate installation of the sensors at the experimental sites. The authors would like to thank the reviewers for their careful reviews and for their suggestions which led to improvement of the original manuscript. The last author wishes to dedicate this work to the memory of his late mentor, colleague and friend Milo Hoffman who passed away recently.

\section{References}

Bowler D.E., Buyung-Ali L., Knight T.M., and Pullin A.S. (2010). Urban greening to cool towns and cities: A systematic review of the empirical evidence. Landscape and Urban Planning, 97(3), 147-155. https://doi.org/10.1016/J.LANDURBPLAN. 2010.05.006.

Giannopoulou K., Livada I., Santamouris M., Saliari M., Assimakopoulos M. and Caouris Y.G. (2011). On the characteristics of the summer urban heat island in Athens, Greece. Sustainable Cities and Society, 1(1), 16-28. https://doi.org/10.1016/J.SCS.2010.08.003.

Livada I., Santamouris M., Niachou K., Papanikolaou N. and Mihalakakou G. (2002). Determination of places in the great Athens area where the heat island effect is observed. Theoretical and Applied Climatology, 71(3-4), 219-230. https://doi.org/10.1007/s007040200006.

Tsianaka E. (2006). The role of courtyards in relation to air temperature of urban dwellings in athens. PLEA 2006 - 23rd International Conference on Passive and Low Energy Architecture, Conference Proceedings, 6.

Tsiros I.X. (2010). Assessment and energy implications of street air temperature cooling by shade tress in Athens (Greece) under extremely hot weather conditions. Renewable Energy, 35(8), 1866-1869. https://doi.org/10.1016/J.RENENE.2009. 12.021.

Tsiros I.X., and Hoffman M.E. (2014). Thermal and comfort conditions in a semi-closed rear wooded garden and its adjacent semi-open spaces in a mediterranean climate (athens) during summer. Architectural Science Review, 57(1), 63-82. https://doi.org/10.1080/00038628.2013.829021.

Wong N.H., Tan C.L., Kolokotsa D.D. and Takebayashi H. (2021). Greenery as a mitigation and adaptation strategy to urban heat. Nature Reviews Earth \& Environment 2021, 2:3, 2(3), 166-181. https://doi.org/10.1038/s43017-020-00129-5.

Zoulia I., Santamouris M. and Dimoudi A. (2009). Monitoring the effect of urban green areas on the heat island in Athens. Environmental Monitoring and Assessment, 156(1-4). 275292. https://doi.org/10.1007/S10661-008-0483-3. 